w Katowicach), którego referat nosił tytuł „Między retoryką a wyobraźnią. Kazania Peregryna z Opola”.

Po zakończeniu obrad w sekcjach, uczestnicy udali się na obiad. Po nim od godz. 16 rozpoczęła obrady ostatnia sekcja pod przewodnictwem ks. prof. Dariusza Zagórskiego. Uczestnicy konferencji mogli w tej części wysłuchać referatów: ks. prof. Leo Eldersa (Rolduc) pt. „Arystoteles w Sumie teologii Tomasza z Akwinu”, ks. dra Piotra Roszaka, który swój referat zatytułował „Jak żyć pod jarzmem? Liturgiczna odpowiedź rytu hiszpańsko-mozarabskiego", ks. prof. Ryszarda Knapińskiego (KUL) pt. „Uniwersalny charakter sztuki średniowiecznej na przykładzie diecezji płockiej”, i mgr Moniki Kamińskiej (Kraków) pt. „Kościół i klasztor bożogrobców w Miechowie - wstępne wyniki badań archeologiczno-architektonicznych”. Po nich nastąpiła krótka przerwa kawowa, po której wznowiono obrady i wysłuchano jeszcze trzech referatów: ks. prof. Mirosława Mroza pt. „Znaczenie pojęcia osoby dla budowania tożsamości europejskiej. Poszukiwania w obszarze myśli św. Tomasza z Akwinu", ks. dr. Alberta Warso (Kongregacja Nauki Wiary, Rzym) który wystąpienie poświęcił wkładowi wyniesionych na ołtarze Polaków doby średniowiecza na kształtowanie się oblicza Polski i Europy, oraz dr. Jacka Zinkiewicza (Muzeum Historyczne Miasta Krakowa), który przedstawiał wyniki swoich badań nad wizjami końca świata w anglosaskiej Anglii. Także ta sekcja przyniosła ciekawą dyskusją, w której kolejny raz szereg cennych uwag i uzupełnień przyniosły wypowiedzi prof. Haliny Manikowskiej. Dwudniową konferencje już po godz. 20 zakończył krótko ks. prof. Dariusz Zagórski, dziękując wszystkim za dwa dni, w których nie brakowało ciekawych referatów i niemal niekończących się dyskusji.

Radostaw Krajniak (Toruń)

\title{
Sprawozdanie z obchodów jubileuszu 90. rocznicy urodzin Pro- fesora Andrzeja Tomczaka, 12 X 2012 r.
}

W 2012 roku obchodzono jubileusz 90. urodzin Andrzeja Tomczaka. 12 października tego roku obchody urodzin profesora odbyły się na Uniwersytecie Mikołaja Kopernika w Toruniu. Uroczystość miała miejsce w Sali Rady Wydziału Nauk Historycznych. Gospodarzem był Dziekan WNH prof. 
Jacek Gzella, który powitał wszystkich gości m.in. JM Rektora UMK prof. Andrzeja Tretyna, senatora Jana Wyrowińskiego oraz zgromadzonych przyjaciół i współpracowników Andrzeja Tomczaka. W uroczystości wzięło udział łącznie ponad dziewięćdziesięciu gości z całej Polski.

Jako pierwszy głos zabrał Jan Wyrowiński, który jako wicemarszałek Senatu oraz Przewodniczący Rady Fundacji Generał Elżbiety Zawackiej, przekazał medal Senatu Rzeczypospolitej Polskiej dla profesora Tomczaka.

Następnie Janusz Tandecki przybliżył sylwetkę Jubilata, w której oprócz życiorysu, zawarł również dokonania naukowe Andrzeja Tomczaka. Po wystąpieniu Dziekan Gzella oddał głos JM Rektorowi, który wyraził swoje ubolewanie, że późno poznał Andrzeja Tomczaka, miało to miejsce w Klubie Profesora UMK. W sposób symboliczny Rektor Tretyn, pragnął uścisnąć dłoń Jubilata, który znał osobiście pierwszego rektora uniwersytetu, a następnie przekazał list gratulacyjny.

Dziekan przekazał głos Jerzemu Wyrozumskiemu, który przeczytał list gratulacyjny od Polskiej Akademii Umiejętności, podpisany przez prezesa Andrzeja Białasa oraz sekretarza PAU w jego osobie.

Krzysztof Mikulski, jako były prezes Polskiego Towarzystwa Historycznego oraz przewodniczący Rady Archiwalnej, złożył gratulacje w imieniu obecnego prezesa PTH Jana Szymczaka.

Następny głos należał do przyjaciółki profesora Tomczaka - Elżbiety Wejmann, która złożyła serdeczne życzenia dla Jubilata oraz uraczyła przybyłych gości historią trudnej, ze względu na zawieruchę wojenną i czasy okupacji, przyjaźni z Andrzejem Tomczakiem.

Po krótkiej historii przedstawionej przez panią Elżbietę głos zabrali przedstawiciele władz archiwalnych. Kolejno listy gratulacyjne i życzenia przekazali: dyrektor AP w Łodzi - Piotr Zawilski, który odczytał również życzenia od Prezesa Stowarzyszenia Archiwistów Polskich - Kazimierza Jaroszka oraz Andrzej Biernat z NDAP, który podziękował w imieniu Naczelnej Dyrekcji Archiwów Państwowych i przeczytał list gratulacyjny od Władysława Stępniaka - Naczelnego Dyrektora Archiwów Państwowych.

Wyjątkowe życzenia w postaci wiersza Jana Kasprowicza pt. Witajcie kochane góry, przeczytała Janina Huppental, reprezentantka toruńskich bibliofilów, których członkiem od ponad 30 lat jest profesor Tomczak.

Dalsze życzenia i gratulacje złożyli przedstawiciele środowisk naukowych i akademickich: profesor Maria Koczerska z UW oraz dr Hanna Krajewska z Polskiej Akademii Nauk.

Następnie głos zabrała była seminarzystka profesora Tomczaka, a obecna dyrektor AP w Toruniu - Beata Herdzin, która podziękowała za lata pracy naukowej oraz życzyła dalszych sukcesów, do życzeń dołączył się dyrektor AP w Bydgoszczy - Eugeniusz Borodij. 
Dalsze życzenia popłynęły z Uniwersytetu Marii Curie Skłodowskiej w Lublinie, które złożyli prof. Krzysztof Skupieński oraz prof. Janusz Łosowski oraz z Uniwersytetu Adama Mickiewicza w Poznaniu, odczytane przez prof. Irenę MamczakGadkowską.

Wielu lat w zdrowiu oraz dalszej pracy naukowej życzyli Jubilatowi: Henryk Krystek z AP w Poznaniu, Przemysław Wojciechowski z redakcji „Rocznika Toruńskiego" oraz Hubert Wajs z Archiwum Głównego Akt Dawnych.

Wielką niespodziankę Jubilatowi sprawiła wizyta emerytowanego szefa zakładu archiwistyki w Centralnym Archiwum Wojskowym - Bolesława Woszczyńskiego, który do serdecznych gratulacji dołożył życzenie następnego jubileuszu urodzin.

Na końcu życzenia złożyli najbliżsi współpracownicy profesora Tomczaka. Zaczął zastępca dyrektora Instytutu Historii i Archiwistyki UMK - Jarosław Kłaczkow. Następnie profesor Wiesława Kwiatkowska z Zakładu Archiwistyki, która oprócz gratulacji od pracowników, przeczytała życzenia nadesłane pocztą z Polski i zagranicy. Profesor Halina Robótka przekazała życzenia od pracowników i doktorantów z Zakładu Zarządzania Dokumentacją i Informacji Archiwalnej.

Dziekan Gzella podziękował za liczne przybycie i życzenia, by następnie przekazać głos Andrzejowi Tomczakowi. Jubilat podziękował za sympatie, uznanie oraz zaskakująco liczne przybycie. Wyrazy wdzięczności pokierował do osób, które go wszystkiego nauczyły, przez lata służyły pomocą, a których niestety już wśród nas nie ma.

Na koniec profesor Waldemar Chorążyczewski zaprezentował księgę pamiątkową dedykowaną Andrzejowi Tomczakowi, która została wydana przez SAP i NDAP. Silva rerum opera hisorica, diplomatica et archivistica, continens, Andreae Tomczak dedicata z założenia miało być zbiorem artykułów naukowych, które dotyczą spraw ważnych dla profesora Tomczaka, zarówno ze względów życiowych, jak i zainteresowań naukowych.

Po krótkich podziękowaniach Dziekan Jacek Gzella zakończył spotkanie i zaprosił przybyłych gości na bankiet. 